\title{
Composition Analysis of Vegetation in Sub-Sub DAS Khilau Kabupaten Pesawaran
}

\author{
Atikah Badzlina*1, Irwan Sukri Banuwa ${ }^{1,2}$, Afif Bintoro ${ }^{1,3}$, Duryat ${ }^{1}$ \\ ${ }^{1} J u r u s a n$ Kehutanan Fakultas Pertanian Universitas Lampung; Jl. Soemantri Brojonegoro, Gedung Meneng, \\ Bandar Lampung, 35145, Lampung, Indonesia \\ ${ }^{2}$ Fakultas Pertanian Universitas Lampung; Jl. Soemantri Brojonegoro, Gedung Meneng, Bandar Lampung, \\ 35145, Lampung, Indonesia \\ ${ }^{3}$ Pascasarjana IImu Kehutanan Fakultas Pertanian Universitas Lampung; Jl. Soemantri Brojonegoro, Gedung \\ Meneng, Bandar Lampung, 35145, Lampung, Indonesia \\ *JI. Rawa Subur, No. 32A Enggal, Bandar Lampung, 35118, Lampung, Indonesia \\ Email : atikahlugo@gmail.com
}

\begin{abstract}
The changes of land use are often affects biodiversity. Eventually, it would affect the composition of the vegetation in the protected forest in KPHL Kabupaten Pesawaran especially in Sub-sub-watershed Khilau. This study aimed to analyze the composition of the vegetation on the various classes of land cover in Sub-sub-watershed Khilau. The main location of the study was conducted in the CCCD site project area. The used method was vegetation analysis with checkered lines as a sampling method. The results of the vegetation analysis of the entire important species growth phase that were found with the largest number was 78 species from each land cover in the tree phase. The lowest number was 33 species in the sapling phase, not even in the seedling phase was found in each land cover. Rehabilitation is urgently needed to maintain functions in the protected areas of the Khilau watershed.
\end{abstract}

Keywords: vegetation analysis, composition, protected forest

\section{PENDAHULUAN}

Kegiatan pemanfaatan dan pengelolaan daerah aliran sungai (DAS) menjadi hal yang sangat penting untuk menjaga ekologi dan ekosistem kawasan lindung. Penurunan fungsi lahan tentunya akan mengakibatkan terjadinya penurunan habitat, fragmentasi, pergantian spesies akibat migrasi dan degradasi habitat aquatik (Surni, 2015). Pertumbuhan penduduk yang semakin meningkat menimbulkan tingginya ketergantungan masyarakat akan sumberdaya lahan. Menurut Pratama dan Yuwono (2016) penggunaan lahan merupakan tindakan yang sangat berpengaruh terhadap tata air dalam fungsi dari suatu daerah aliran sungai (DAS).

Sub-sub-DAS Khilau saat ini sangat membutuhkan kegiatan rehabilitasi lahan untuk mengatasi permasalahan penggunaan lahan yang tidak sesuai dengan daya dukungnya. Menurut Soerianagara dan Indrawan (1998) analisis vegetasi dalam ekologi tumbuhan merupakan cara untuk memelajari struktur dan komposisi jenis vegetasi tumbuhan.

Penggunaan keanekaragaman hayati pada kawasan lindung yang tidak bijaksana oleh penduduk setempat akan 
berdampak merusak, sehingga penggunaan bersangkutan harus dibatasi atau dihentikan, menurut hukum adat atau tidak (Barber dkk, 1997). Oleh sebab itu dibutuhkan kegiatan analisis vegetasi untuk mengetahui komposisi jenis (susunan) vegetasi yang berada di KPHL Pesawaran.

\section{METODE}

Penetapan lokasi utama penelitian dilakukan pada wilayah site project Cross Cutting Capacity Development (CCCD). Alat yang digunakan dalam penelitian adalah Global Positioning System (GPS), hagameter, kamera, pita ukur dengan ketelitian $0,01 \mathrm{~mm}$, tali rapia, tally sheet, milimeter blok dan alat tulis. Bahan yang digunakan pada penelitian ini adalah vegetasi di hutan lindung register 21 $\mathrm{KPH}$ Pesawaran serta peta $\mathrm{RBI}$ dengan skala 1:75.000 daerah administrasi Pesawaran dan Pringsewu, peta kemiringan lahan, peta tutupan lahan, dan peta Sub-sub-DAS Khilau. Lokasi penelitian dapat dilihat pada Gambar 1.

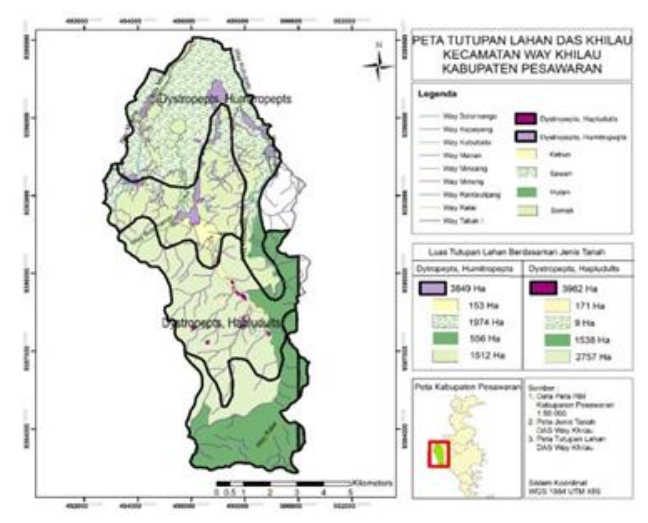

Gambar 1. Peta tutupan lahan lokasi penelitian.

Metode yang digunakan adalah analisis vegetasi dengan garis berpetak sebagai metode sampling. Metode garis berpetak ini dipilih dengan alasan pelaksanaan lebih cepat dan sederhana serta kesalahan yang timbul paling kecil dibandingkan metode yang lain (Simon, 1996).

Penelitian ini terdiri dari 5 perlakuan yang sesuai dengan bentuk tutupan lahan yaitu tutupan lahan hutan primer, agroforestri, perladangan semusim, semak belukar dan persawahan dengan pengulangan sebanyak 4 (empat) kali, pada tiap bentuk penggunaan lahan. Jumlah keseluruhan plot sampel yang digunakan yaitu 20 plot untuk mengetahui komposisi, struktur dan keanekaragaman jenis vegetasi di Subsub-DAS Khilau.

Petak ukur persegi data yang diambil adalah tegakan pada tingkatan pohon dalam petak $20 \times 20 \mathrm{~m}$, pada tingkat tiang dalam petak $10 \times 10 \mathrm{~m}$, pancang dalam petak $5 \times 5 \mathrm{~m}$ dan permudaan atau semai, terna, herba, perdu, liana ataupun epifit dengan ukuran petak $2 \times 2 \mathrm{~m}$ (Heddy, 2012). Analisis data meliputi perhitungan persentase kerapatan, frekuensi, dominansi dan indeks nilai penting.Menurut Indriyanto (2008) indeks keanekaragaman merupakan suatu parameter untuk membandingkan berbagai komunitas tumbuhan.

\section{HASIL DAN PEMBAHASAN}

Keanekaragaman tumbuhan pada hutan berfungsi sebagai sumber pangan, sandang, papan, dan juga penghasil oksigen dan pereduksi karbondioksida dari atmosfer serta sebagai habitat flora dan fauna (Soerianegara, 1978). Hasil analisis vegetasi pada fase pertumbuhan meliputi pohon, tiang, pancang dan semai yang terbagi dalam lima kelas tutupan lahan sangat beragam. Hasil data jenis dan jumlah spesies penting dapat dilihat pada Tabel 1. 
52 / Badzlina, A., I. S. Banuwa, A. Bintoro, Duryat

Tabel 1. Hasil spesies penting tumbuhan tingkat pohon di Sub-sub-DAS Khilau

\begin{tabular}{|c|c|c|c|}
\hline $\begin{array}{l}\text { Jenis Tutupan } \\
\text { Lahan }\end{array}$ & $\begin{array}{l}\text { Fase } \\
\text { Pertumbuhan }\end{array}$ & $\Sigma$ spesies & Spesies penting (Dominan) \\
\hline Hutan primer & Pohon & 32 & Kemiri (Aleurites moluccana) (INP=39,33\%) \\
\hline Agroforestri & & 25 & Jati (Tectona grandis) $(\mathrm{INP}=59,61 \%)$ \\
\hline $\begin{array}{l}\text { Perladangan } \\
\text { semusim }\end{array}$ & & 4 & Durian (Durio zibethinus) (INP=120,64\%) \\
\hline Semak belukar & & 13 & Kemiri (Aleurites moluccana) $(\mathrm{INP}=84,15 \%)$ \\
\hline Persawahan & & 4 & Mangga (Mangifera indica) (INP=83,47\%) \\
\hline Jumlah & & 78 & \\
\hline Hutan primer & Tiang & 20 & $\begin{array}{l}\text { Kapur Sintuk (Dryobalanops oocarpa) } \\
(\mathrm{INP}=56,88 \%)\end{array}$ \\
\hline Agroforestri & & 13 & Gamal (Gliricidia sepium) (INP=91,89\%) \\
\hline $\begin{array}{l}\text { Perladangan } \\
\text { semusim }\end{array}$ & & 13 & Dadap (Erythrina sp.) (INP=92,12\%) \\
\hline Semak belukar & & 12 & Petai (Parkia speciosa) (INP=93,87\%) \\
\hline Persawahan & & 6 & Maja (Crescentia cujete) $(\mathrm{INP}=300,00 \%)$ \\
\hline Jumlah & & 64 & \\
\hline Hutan primer & Pancang & 0 & Tidak ditemukan \\
\hline Agroforestri & & 4 & Gamal (Gliricidia sepium) (INP=174,06\%) \\
\hline $\begin{array}{l}\text { Perladangan } \\
\text { semusim }\end{array}$ & & 14 & Gamal (Gliricidia sepium) (INP=83,52\%) \\
\hline Semak belukar & & 12 & Alkosah $(\mathrm{INP}=98,29 \%)$ \\
\hline Persawahan & & 3 & Maja (Crescentia cujete) $(\mathrm{INP}=152,87 \%)$ \\
\hline Jumlah & & 33 & \\
\hline Hutan primer & Semai & 6 & $\begin{array}{l}\text { Rumput ilalang (Imperata cylindrica) } \\
(\mathrm{INP}=100,00 \%)\end{array}$ \\
\hline Agroforestri & & 11 & Rumput betung (Equisetum debile) (INP=72,72\%) \\
\hline $\begin{array}{l}\text { Perladangan } \\
\text { semusim }\end{array}$ & & 9 & Rumput pegaga (Centella asiatica) $(\mathrm{INP}=88,88 \%)$ \\
\hline Semak belukar & & 12 & Rumput ilalang (Imperata cylindrica) (INP=66,66\%) \\
\hline Persawahan & & 5 & Padi (Oryza sativa) (INP=160,00\%) \\
\hline Jumlah & & 43 & \\
\hline
\end{tabular}

Hasil informasi dari masyarakat sekitar kawasan diketahui hampir sebagian besar bermata pencaharian petani dan memiliki lahan yang berada di register 21. Masyarakat pada umumnya menggarap di dalam kawasan hutan dengan pola tanam agroforestri dan tanaman semusim. Jenis tanaman yang mendominasi yaitu tanaman kakao, kopi, lada dan cengkeh. Serta untuk pola tanaman semusim yaitu sayuran, padi dan jagung.

Analisis vegetasi bertujuan untuk mengetahui berbagai jenis vegetasi dalam suatu komunitas atau populasi tumbuhan yang berkembang dalam skala waktu dan ruang. Hasil data jenis dan jumlah spesies penting pada fase tingkat 
pohon berjumlah 78 spesies. Data tersebut menjadi data terbanyak dalam katagori jumlah spesies terutama spesies yang mendominasi yaitu Durian (Durio zibetinus) (INP=120,64\%) dan Kemiri (Aleurites moluccana) (INP=84,15\%). Hasil analisis jenis dan jumlah spesies penting tumbuhan yang berada pada fase tingkat tiang berjumlah 64 spesies. Spesies penting dengan jumlah 20 spesies pada tutupan lahan hutan primer yaitu Kapur Sintuk (Dryobalanops oocarpa) (INP $=56,88 \%)$.Jenis yang memiliki nilai INP yang tinggi menunjukkan bahwa jenis-jenistersebut merupakan jenis yang lebih adaptif terhadaplingkungan, selain itu juga suatu jenis dikatakan dominan dalam komunitas apabila jenis tersebut berhasil memanfaatkan sebagian besar sumber daya yang ada untuk pertumbuhan hidupnya dibandingkan dengan jenis yang lain (Rahayu 2006).

Hasil analisis pada fase tingkat pancang tutupan lahan hutan primer bahwa tidak ditemukannya spesies penting di dalamnya. Data pada Tabel 1 terlihat jumlah spesies pada fase pancang yaitu 33 spesies. Hal ini disebabkan terlihat beberapa tanaman masyarakat yang mulai memasuki kawasan hutan primer seperti kakao dan kopi. Dendang dan Handayani (2015), menyatakan bahwa tidak semua jenis vegetasi selalu ditemukan pada setiap tingkat pertumbuhan.

Hasil data pada fase semai tidak ditemukannya spesies penting dari tegakan yang berada di seluruh kelas tutupan lahan. Sebagian besar lantai hutan terdiri dari tumbuhan bawah berupa semak dan tanaman herba. Hal ini sangat mempengaruhi regenerasi hutan di kawasan lindung Sub-sub DAS Khilau. Berdasarkan penelitian Hidayat (2015) bahwa tindakan konservasi yang menguntungkan semua pihak sangat perlu dilakukan untuk mempertahankan status hutan lindung.

\section{KESIMPULAN}

Hasil data keseluruhan fase pertumbuhan spesies penting ditemukan sebanyak 78 spesies dari setiap tutupan lahan pada fase pohon. Jumlah terendah yaitu 33 spesies yang berada pada fase pancang, bahkan tidak ditemukannya fase semai di setiap tutupan lahan. Kegiatan rehabilitasi hutan sangat dibutuhkan pada Sub-sub DAS Khilau untuk menjaga fungsinya sebagai kawasan lindung.

\section{UCAPAN TERIMAKASIH}

Tim peneliti mengucapkan terima kasih kepada Kesatuan Pengelolaan Hutan (KPH) Pesawaran atas izin penelitian yang diberikan. Ucapan terima kasih juga disampaikan kepada staf dan polisi hutan $\mathrm{KPH}$ Pesawaran yang telah banyak memberikan bantuanselama penelitian.

\section{DAFTAR PUSTAKA}

Barber, C.V., Afif, S. dan Purnomo, A. (1997). Meluruskan Arah Pelestarian Keanekaragaman Hayati dan Pembangunan di Indonesia. Jakarta: Yayasan Obor Indonesia.

Dendang, B. dan Handayani, W. (2015). Struktur dan komposisi tegakan hutan di Taman Nasional Gunung Gede Pangrango, Jawa Barat.Pros sem nas masy biodiv indon. 1(4).

Heddy, S. (2012). Metode Analisis Vegetasi dan Komunitas. Jakarta: Penerbit Raja Rafindo Persada.

Hidayat, S. (2015). Komposisi dan struktur tegakan penghasil kayu bahan bangunan di hutan lindung Tanjung Tiga, Muara Enim, Sumatera Selatan. Jurnal Manusia dan Lingkungan. 22(2), 194-200.

Indriyanto. (2008). Ekologi Hutan. Bumi Aksara. Jakarta. 
Pratama, W. dan Yuwono, S. B. (2016). Analisis perubahan penggunaan lahan terhadap karakteristik hidrologi di DAS Bulok. Jurnal Sylva Lestari. 4(3), 11-20.

Rahayu, W. (2006). Suksesi Vegetasi Di Gunung Papandayan Pasca Letusan Tahun 2002. Skripsi. Departemen Manajemen Hutan, Fakultas Kehutanan, Institut Pertanian Bogor. Bogor. Tersedia dari Repostory IPB. (UT - Forest Management [1538]).

Simon, H. (1996). Metode Inventore Hutan. Yogyakarta: Aditya Media.
Soerianegara, (1978). Ekologi Hutan Indonesia. Bogor: Departemen Manajement Hutan. Fakultas Kehutanan. IPB.

Soerianegara, I., dan Indrawan, A. (1998). Ekologi Hutan Indonesia. Bogor: Laboratorium Ekologi Hutan. Fakultas Kehutanan IPB.

Surni, Baja, S., dan Arsyad, U. (2015). Dinamika perubahan penggunaan lahan, penutupan lahan terhadap hilangnya biodiversitas di DAS Tallo Sulawesi Selatan. Pros sem nas masy biodiv indon. 1(5), 10501055. 